\title{
二流路系を用いた洗剤の溶媒抽出/フローインジェク ション分析
}

\author{
本水 昌二 ${ }^{\circledR}$ ，是近 勝彦*
}

(1989 年 5 月 1 日受理)

\begin{abstract}
洗剤（陰イオン界面活性剂）の抽出/FIA について，実用分析の観点から，装置面と試薬面について 再検討した。プランジャ一型ポンプを用い, 従来の三流路系を二流路系とし, 試薬溶液流れに試料を注 入した。ポンプについて検討したところ, ダブルプランジャー型ポンプ1台で間に合い, 三流路法と比 較しても, 感度的にはほぼ同程度であることが分かった。内径 $0.5 \mathrm{~mm}$, 長さ $1 \mathrm{~m}$ 以上のポリテトラフ ルオロエチレン製チューブを抽出コイルとして用いたとき，長さ $25 \mathrm{~mm}$ と約 $2 \mathrm{~mm}$ のセグメントにお いてピーク高さはほとんど同じであった。陰イオン界面活性剤の対イオンとなる染料陽イオンについて は, メチレンブルー (MB) (抽出溶媒 : o-ジクロロベンゼン) と 1-メチル-4-(4-ジエチルアミノフェニ ルアゾ)ピリジニウムイオン（MEP）（抽出溶媒：クロロホルム）を比較した。二つの染料陽イオンを 比較すると, MB 法のほうが感度は高いが, 試薬から試験液のピークが負ピークとなり, 又ピークのテ イリングが大きいため, 分析所要時間が若干長い. $1 \times 10^{-6} \mathrm{M}$ ラウリル硫酸ナトリウムを 10 回注入し たときのピーク高さ，標準偏差及び相対標準偏差は MB 法でそれぞれ，200.6 mm, $0.8 \mathrm{~mm}$ 及び $0.4 \%$, MEP 法でそれぞれ， $121.1 \mathrm{~mm} ， 0.3 \mathrm{~mm}$ 及び $0.3 \%$ であった. $S / N=3$ に相当する検出限界は両法に おいて約 $1 \times 10^{-8} \mathrm{M}$ であるが，実際の定量下限は $3 \times 10^{-8} \mathrm{M}$ 程度となる. 分析所要時間は, 1 サンプ ル当たり MEP 法で 2 分, MB 法で 3 分 (流量 $0.6 \mathrm{ml} \mathrm{min}^{-1}$ の場合) 及びメチレンブルー法で 2 分 (流 量 $0.8 \mathrm{ml} \mathrm{min}^{-1}$ の場合）となる.
\end{abstract}

\section{1 緒言}

洗剤（陰イオン界面活性剤）の吸光光度法は主に染料 陽イオンを用いるイオン会合体の溶媒抽出法に基づいて いる. JIS 法など1)2)ではメチレンブルー（MB と略 記）を用いるクロロホルム抽出法が推奨されているが, 2 3 回の抽出操作と有機相の洗浄操作を必要とする煩 雑な定量法である. 操作の簡便化, 迅速化, 高感度化を 目的として, バッチ法ではエチルバイオレットを用いる トルエン抽出法も報告されている3) -5). 現在, 操作の 簡便化, 迅速化, 高感度化そして自動化を目指して FIA 法の研究が盛んである. FIA 法の大きな利点の一 つはさまざまな前処理操作を流れ系に容易に組み込むこ とができることである，溶媒抽出の FIA への組み込み は Karlberg らにより始められだ). Kawase らはポリテ トラフルオロエチレン（PTFE と略記）膜を用いる相分 離器を提案した ${ }^{7)}$. 著者らは Imasaka $ら^{8)}$ の考案した相 分離器を若干改良したものを用いることにより河川水, 湖沼水中の微量の洗剤の定量を可能とした ${ }^{9) 10)}$.

* 岡山大学理学部 : 700 岡山県岡山市津島中 3-1-1
本報告は既報910)における FIA 流路系の単純化と染 料陽イオンの比較を実用的観点から検討したものであ る.

$$
2 \text { 実験 }
$$

\section{$2 \cdot 1$ 試 薬}

洗剤標準溶液 : ラウリル硫酸ナトリウム $\left(\mathrm{LS}^{-}\right.$和光 純薬工業, 純度 $99.2 \%)$ を恒量值を得るまで堿圧下乾 燥 $\left(3 \mathrm{mmHg}, 50^{\circ} \mathrm{C}\right)$ したものを水に溶かして用いた。 $10^{-2} \mathrm{M}$ 溶液を調製し，使用前に適宜希釈して用いた。

試薬溶液 (RS) : 染料陽イオンとしてメチレンブルー (MB) (東京化成工業, 純度 $98.5 \%$ 以上）及び既報 ${ }^{9}$ と 同様に, 合成した 1-メチル-4-(4-ジエチルアミ)フェニ ルアゾ) ピリジニウム塩 (MEP) (対陰イオンとして $\mathrm{I}^{-}$と $\mathrm{Cl}^{-}$のもの) を用いた。 なお MEP としては市販 品 (東京化成工業, MDEPAP) も比較検討したが, 著 者らの合成品と同様の結果が得られた. $\mathrm{Cl}^{-}$型の MEP 溶液は既報之同様, 陰イオン交換カラム $\left(\mathrm{Cl}^{-}\right.$型 $)$に て $\mathrm{I}^{-}$型を $\mathrm{Cl}^{-}$型に変えた。二流路系では, $2 \times 10^{-5}$ $\mathrm{M}$ 染料陽イオンと $0.05 \mathrm{M} \mathrm{Na}_{2} \mathrm{SO}_{4}$ を含む $\mathrm{pH} 5$ (酢酸 緩衝液, $0.01 \mathrm{M}$ ) の溶液を試薬溶液 (RS) とし, 三流 
路系ではすべて 2 倍の濃度のものを用いた.

抽出溶媒 : MB 法では，既報 ${ }^{10)}$ と同様，o-ジクロロベ ンゼンを用いた，MEP 法では，既報帛と同様，クロロ ホルムを用いた.クロロホルムは蒸留水で水洗後用い た。

\section{$2 \cdot 2$ 装 置}

抽出 FIA の概略流れ図を Fig. 1 に示す. 各コネク ター類の接続チューブ, 反応コイル，抽出コイルなどに は内径 $0.5 \mathrm{~mm}$ の PTFE チューブを用いた。 ポンプは サヌキ工業製ダブルプランジャー型ポンプ (DM2M-1016) 及びシングルプランジャー型ポンプ （IP2U-4017）を用いた（いずれもプランジャー径は 2.5 $\mathrm{mm}$ ，ストローク長は $1 \mathrm{~mm})$. 相分離器は既報 ${ }^{9) 10)}$ と同 様のものを用いた，吸光度は $18 \mu \mathrm{l}$ のフローセルを取り 付けた相馬光学製波長可変 FIA 検出器 S-3250 型を用 い, MB-o-ジクロロベンゼン抽出系（以下 MB 法とい

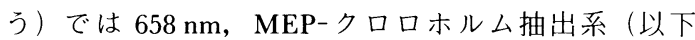
MEP·Cl 法又は MEP·I 法という) では $564 \mathrm{~nm}$ で測定 し，東亜電波工業製記録計 FBR-251A により記録し た. 又, 日立 D-2000 Chromato-Integrator によりピー ク面積を求めた.

\section{3 結果及び考察}

\section{$3 \cdot 1$ 三流路系と二流路系の比較}

既報 ${ }^{9)}{ }^{10)}$ では 2 台のダブルプランジャ一型ポンプ $\mathrm{P}_{\mathrm{D} 1}$ と $\mathrm{P}_{\mathrm{D} 2}$ を用い, Fig. 1(a) の流路で行った. $\mathrm{P}_{\mathrm{D} 2}$ の二つ のプランジャーを用いる（b）の流路系と（a）を比較 すると若干（b）のほうがセグメントが規則正しく形成 されるが，ピーク形状にはほとんど差はない。(a), （b）においては $\mathrm{P}_{\mathrm{D} 1}$ と $\mathrm{P}_{\mathrm{D} 2}$ の送液量を変えることによ り, 抽出濃縮又は抽出希釈が可能である. 又, サンプル 注入量を増すにつれてピーク面積は直線的に増加する. 例えば MB 法では注入量とピーク面積との関係は原点 を通り，1000 $\mu \mathrm{l}$ 程度まで直線性がある．900 $\mu \mathrm{l}$ 程度ま でのサンプル注入量に対してはピーク高さも次第に高く なる・

(c)，(d)，（e）の二流路系では，Fig. 2 に示すよう に，試料注入量が多くなると試料との混合が不十分とな り，ピークはダブルピークとなる．このため，Fig. 3 に 示すように試料注入量とピーク面積とは， $40 ３ 00 \mu \mathrm{l}$ の 範囲では直線関係を示しているが，原点は通らない，更 に $300 \mu \mathrm{l}$ 以上では直線から外れてくる. 又，染料陽イ オンがハロゲン化物イオンを伴って，一部抽出されてい る場合（MB 法，MEP·I 法）には，洗剤を含まない試 料あるいは低濃度の試料を注入したとき，二流路系では 負のピークを与える (Fig. 9). MB 法では $0.3 \times 10^{-7}$ M 以下の洗剤を注入したとき負のピークとなるが, $\mathrm{MEP} \cdot \mathrm{Cl}$ 法ではもともと $\left(\mathrm{MEP}^{+} \cdot \mathrm{Cl}^{-}\right)$イオン会合体 はほとんど抽出されていないので，負のピークは生じな い.しかし，対陰イオンが $\mathrm{I}^{-}$の $\mathrm{MEP} \cdot \mathrm{I}$ 溶液を用いる と, ベースラインは $10^{-6} \mathrm{M}$ 程度の $\left(\mathrm{MEP}^{+} \cdot \mathrm{I}^{-}\right)$イオ ン会合体が抽出された状態であり，低濃度試料では大き な負のピークを与える，ピーク高さから考えれば，MB (a)

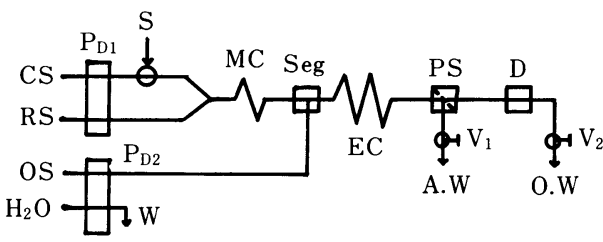

(b)

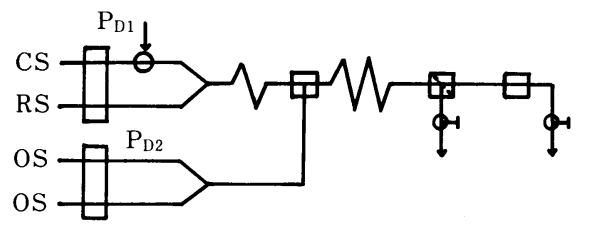

(c)

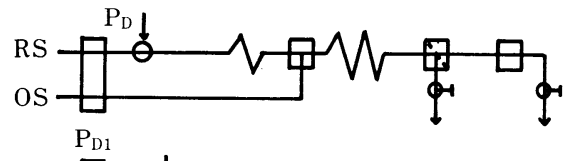

(d)

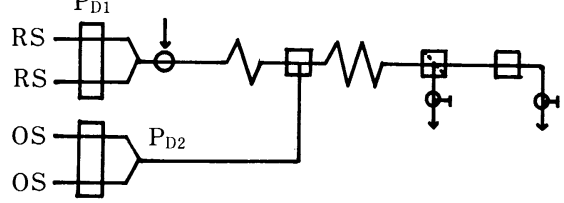

(e)

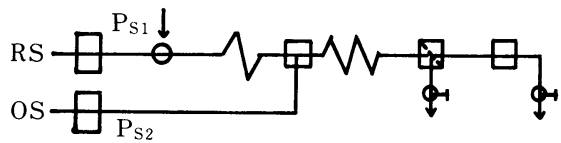

Fig. 1 Schematic diagram of FIA system

CS : carrier (distilled water); RS : reagent solution; OS : extracting solvent; $P_{D}, \quad P_{D 1}, P_{D 2}$ : double-plunger pump; $\mathrm{P}_{\mathrm{S} 1}, \mathrm{P}_{\mathrm{S} 2}$ : single-plunger pump; $\mathrm{S}$ : sample injection; $\mathrm{MC}$ : mixing coil ; Seg : segmentor (T-shape); EC : extraction coil ; PS : phase separator; D : spectrophotometric detector; $\mathrm{V}_{1}, \mathrm{~V}_{2}$ : needle valve; $\mathrm{A} . \mathrm{W}$ : aqueous phase waste; O.W : organic phase waste; $\mathrm{W}$ : waste. Bore of the tubing : $0.5 \mathrm{~mm}$ i.d. 


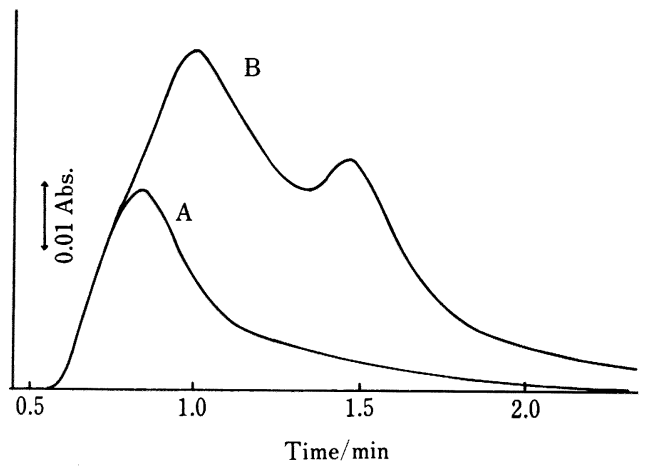

Fig. 2 Effect of sample size on peak shape

Method : MEP.Cl method; Mixing coil : $30 \mathrm{~cm}$; Extraction coil : $1 \mathrm{~m}$; Sample size : A, $170 \mu \mathrm{l}$; B, $460 \mu \mathrm{l}$; Sample : $10^{-6} \mathrm{M} \mathrm{LS}^{-}$

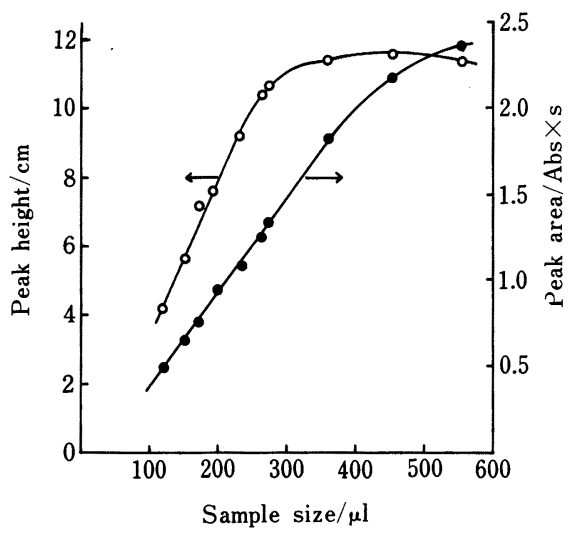

Fig. 3 Effect of sample size on peak height and peak area

Method : MEP.Cl method ; Sample : $10^{-6} \mathrm{M} \mathrm{LS}^{-}$

法のほうが高感度であるが, 数 ppb の洗剂定量の場合 には MEP·Cl 法が実際上は有利である.

\section{$3 \cdot 2$ 混合コイル長のピーク形状に与える影響}

二流路系では試料と試薬溶液の混合のための混合コイ ルが必要である. $0.3 \mathrm{~m} \sim 1.5 \mathrm{~m}$ 長のものについて検討 した. Fig. 4 に得られたシグナルの一部を示す.チュー ブが長くなるにつれて，ピークはシャープになりピーク 高さも大きくなっている.これは PTFE チューブ表面 が疎水性であり, 疎水性のイオン会合体を吸着しやす く, 一種の吸着カラムの役割をしているため, チューブ が長くなるにつれてピークのリーディングが短くなり,

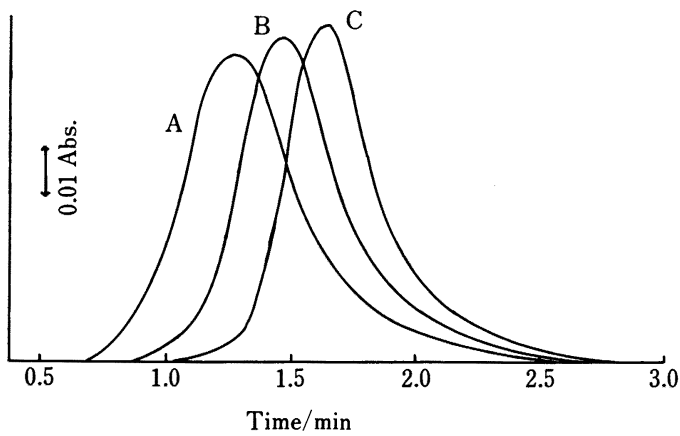

Fig. 4 Effect of mixing coil length on peak shape

Method: MEP.Cl method; Extraction coil : $1 \mathrm{~m}$; Sample size : $350 \mu \mathrm{l}$; Length of the tubing of the mixing coil : A, $50 \mathrm{~cm} ; \mathrm{B}, 100 \mathrm{~cm} ; \mathrm{C}, 150 \mathrm{~cm}$; Sample : $10^{-6} \mathrm{M} \mathrm{LS}^{-}$

このためにピークはシャープになったものと考えられ る. 更に，チューブが長いほゼよく混合されるためピー クも高くなったと考えられる，しかし，ピーク面積 $\left(P_{\mathrm{A}}\right)$ の比は $P_{\mathrm{A}}(0.3 \mathrm{~m}): P_{\mathrm{A}}(1 \mathrm{~m}): P_{\mathrm{A}}(1.5 \mathrm{~m})=1: 0.91:$ 0.84 となり, 長いチューブほどピーク面積は小さくな っている.これはPTFEチューブ表面にイオン会合体 の一部が吸着されてしまうためであろう．事実，長いチ ユーブを用いるほど，一定高さのピークを得るためには より多数回試料を注入しなければならない，例えば 0.3 $\mathrm{m}$ チューブでは最初の一つのピークが約 5\% 低いだけ であるが, $1.5 \mathrm{~m}$ チューブでは 5 6 回目の注入で初め て最高一定のピークが得られる。これらのことを考える と実用的には，ピークは低いが，短いほうが好ましいと 思われる. $1.5 \mathrm{~m}$ と $0.3 \mathrm{~m}$ では後者のピーク高さは約 $15 \%$ 低いが, 以後の実験では後者のものを用いること とした.

$3 \cdot 3$ セグメントの大きさのピーク高さに与える影響 既報910) と同様のセグメンター (孔径 $0.5 \mathrm{~mm}$ の T 字 コネクター）を用い, Fig. 1 の流路（c）で行ったとこ 万 Fig. $5 \mathrm{C}$ に示すように, 水相, 有機相は内径 0.5 $\mathrm{mm}$ の抽出コイル中で長さ $2.5 \mathrm{~cm}$ のセグメントとなっ た.この長さは 1 ストロークの吐出量に相当するもの である. 2 台のダブルプランジャーポンプを用いる (d) では,（b）の三流路系とほぼ同様の約 $8 \mathrm{~mm}$ 長の 規則正しいセグメントとなっている． 2 台のシングルプ ランジャーポンプでは 1 台のダブルプランジャーポン プよりもセグメントは不規則である. 二流路系 (c), (d)，(e) ではセグメントの様子は異なるが，1 m 以上 


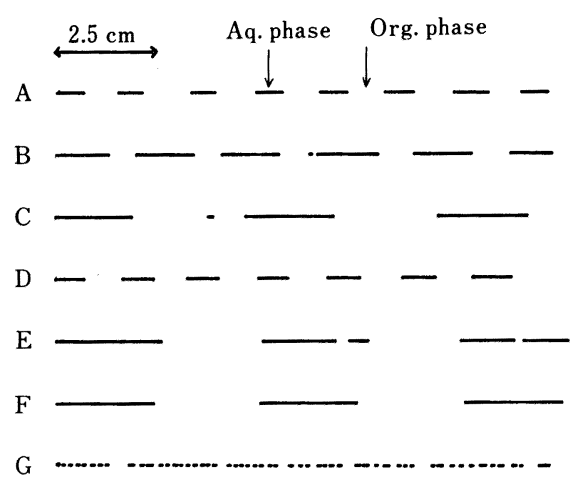

Fig. 5 Comparison of segment length

Flow diagram: A and B, Fig. 1(b); C, F and G, Fig. 1(c); D, Fig. 1(d); E, Fig. 1(e). Segmentor: A $\sim$ E, Fig. 6(a); F, Fig. 6(c); G, Fig. 6(b). Flow rate ratio of aqueous phase to organic phase: $\mathrm{B}$, $2: 1 ; A$ and $\mathrm{C} \sim \mathrm{G}, 1: 1$. Flow rate of organic solvent : $0.6 \mathrm{ml} \mathrm{min}^{-1}$

(a)

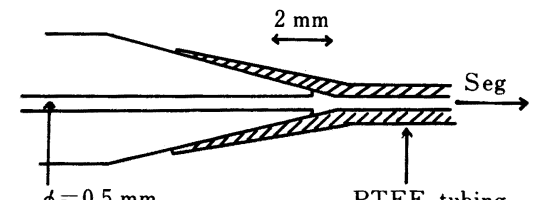

(b)

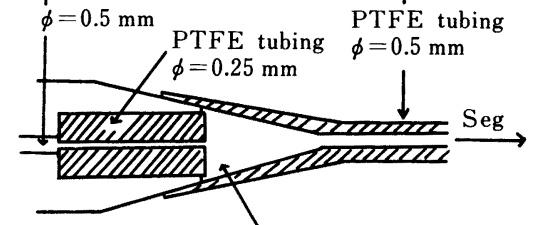

(c)

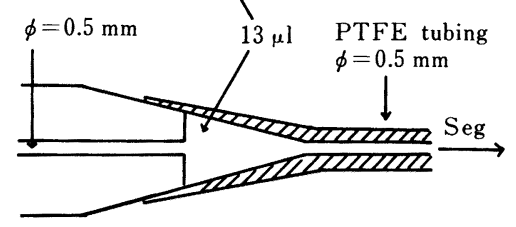

Fig. 6 Segmentor

Figures show outlet of T-shape segmentor. (a) common-type segmentor; (b) improved-type segmentor with $0.25-\mathrm{mm}$ bore connector and $13-\mu \mathrm{l}$ space; (c) segmentor with 0.5 - $\mathrm{mm}$ bore connector and $13-\mu \mathrm{l}$ space; Seg : segment flow

の抽出コイルを用いた場合にはピーク高さにはほとんど 差はない.

小さいセグメントを作るために，七グメンタ一の出口 コネクターを改良した。 Fig. 6 に示すようにコネクター の先端を平らに削り取り，接続するチューブとの間に約 $13 \mu \mathrm{l}$ の空げきを作った. 更にコネクターの出口側に孔

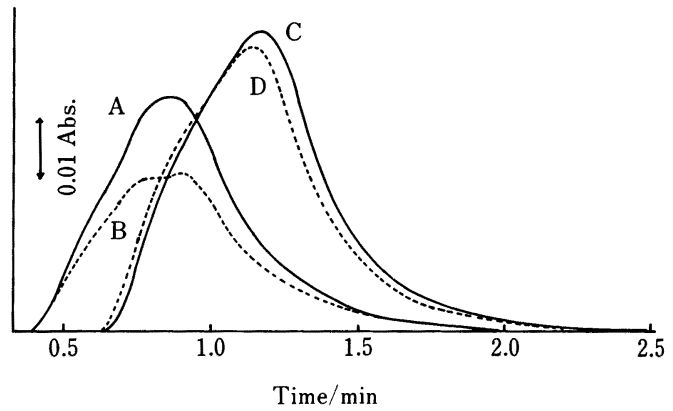

Fig. 7 Comparison of segmentors

Method: MEP.Cl method; Flow diagram: Fig. 1(c); Mixing coil : $30 \mathrm{~cm}$; Extraction tubing : A and $\mathrm{B}, 10 \mathrm{~cm} ; \mathrm{C}$ and $\mathrm{D}, 100 \mathrm{~cm}$; Segmentor: $\mathrm{A}$ and C, Fig. 6(b); B and D : Fig. 6(c); Sample: $10^{-6} \mathrm{M} \mathrm{LS}^{-}$

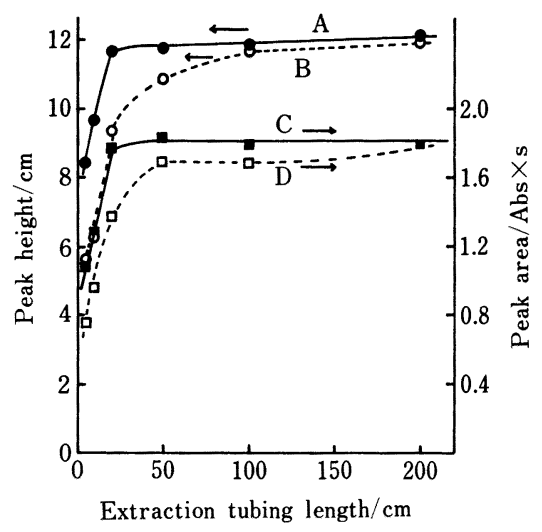

Fig. 8 Effect of extraction coil on peak height and peak area

Method: MEP.Cl method; mixing coil : $30 \mathrm{~cm}$; Segmentor: A and C, Fig. 6(b); B and D : Fig. 6(c); Sample : $10^{-6} \mathrm{M} \mathrm{LS}^{-}$

径 $0.25 \mathrm{~mm}$, 長さ $5 \mathrm{~mm}$ の PTFE チューブを埋め込ん だ。このセグメンターを用い, Fig. 1の（c）の流路系 でピーク形状を比較した。 Fig. 5 の G に示すよう に, 平均 $2 \mathrm{~mm}$ 長の小さいセグメントを作ることがで きた.これは細かい線状の水相が有機相中に射出される ために，小さいセグメントが形成されるものと思われ る. $\mathrm{F}$ と $\mathrm{G}$ のグメントの場合のピーク形状を Fig. 7 に示す.いずれにおいても，小さいセグメントの 場合がピーク高さは大きい. 特に抽出コイルの短い場合 のほうが, 差は大きい (Fig. 8).これは, Imasaka ${ }^{8) ら ~}$ が考察しているように, 小さいセグメントのほうが水 
Table 1 Analytical conditions, reproducibility and detection limit for determination of anionic surfactants

\begin{tabular}{|c|c|c|c|}
\hline & MEP $\cdot$ Cl method & MEP $\cdot$ I method & MB method \\
\hline Mixing coil & $0.5 \mathrm{~mm}$ i.d. $\times 30 \mathrm{~cm}$ & $0.5 \mathrm{~mm}$ i.d. $\times 30 \mathrm{~cm}$ & $0.5 \mathrm{~mm}$ i.d. $\times 30 \mathrm{~cm}$ \\
\hline Extraction coil & $0.5 \mathrm{~mm}$ i.d. $\times 2 \mathrm{~m}$ & $0.5 \mathrm{~mm}$ i.d. $\times 2 \mathrm{~m}$ & $0.5 \mathrm{~mm}$ i.d. $\times 2 \mathrm{~m}$ \\
\hline Sample injection volume & $350 \mu \mathrm{l}$ & $350 \mu \mathrm{l}$ & $350 \mu \mathrm{l}$ \\
\hline \multicolumn{4}{|l|}{ Flow rate: } \\
\hline Reagent stream & $0.6 \mathrm{ml} \mathrm{min}^{-1}$ & $0.6 \mathrm{ml} \mathrm{min}^{-1}$ & $0.6 \mathrm{ml} \mathrm{min}^{-1}$ \\
\hline Extraction solvent stream & $0.6 \mathrm{ml} \mathrm{min}-1$ & $0.6 \mathrm{ml} \mathrm{min}-1$ & $0.6 \mathrm{ml} \mathrm{min}^{-1}$ \\
\hline Flow-through cell $(18 \mu \mathrm{l})$ & $10 \mathrm{~mm}$ path length & $10 \mathrm{~mm}$ path length & $10 \mathrm{~mm}$ path length \\
\hline Reagent solution & $\begin{array}{c}\mathrm{MEP} \cdot \mathrm{Cl}^{\mathrm{a})}, 2 \times 10^{-5} \mathrm{M} \\
\mathrm{Na}_{2} \mathrm{SO}_{4}, 0.1 \mathrm{M} \\
\mathrm{pH} 5\end{array}$ & $\begin{array}{c}\mathrm{MEP} \cdot \mathrm{I}^{\mathrm{b})}, 2 \times 10^{-5} \mathrm{M} \\
\mathrm{Na}_{2} \mathrm{SO}_{4}, 0.1 \mathrm{M} \\
\mathrm{pH} 5\end{array}$ & $\begin{array}{c}\text { Methylene Blue, } 2 \times 10^{-5} \mathrm{M} \\
\mathrm{Na}_{2} \mathrm{SO}_{4}, 0.1 \mathrm{M} \\
\text { pH } 5\end{array}$ \\
\hline Extraction solvent & chloroform & chloroform & $o$-dichlorobenzene \\
\hline Wavelength of detection & $564 \mathrm{~nm}$ & $564 \mathrm{~nm}$ & $658 \mathrm{~nm}$ \\
\hline Linearity of calibration graph & $(0 \sim) \times 10^{-6} \mathrm{M}$ & $(0 \sim) \times 10^{-6} \mathrm{M}$ & $(0 \sim) \times 10^{-6} \mathrm{M}$ \\
\hline Sensitivity ${ }^{c)}$ & $12 \mathrm{~mm} / 10^{-7} \mathrm{M} \mathrm{LS}^{-}$ & $12 \mathrm{~mm} / 10^{-7} \mathrm{M} \mathrm{LS}^{-}$ & $20 \mathrm{~mm} / 10^{-7} \mathrm{M} \mathrm{LS}^{-}$ \\
\hline Standard deviation ${ }^{\text {d) }}$ & $0.3 \mathrm{~mm}$ & $0.4 \mathrm{~mm}$ & $0.8 \mathrm{~mm}$ \\
\hline R.S.D. ${ }^{\text {d) }}$ & $0.3 \%$ & $0.3 \%$ & $0.4 \%$ \\
\hline Detection limit $^{c)}$ & $10^{-8} \mathrm{M}(3 \mathrm{ppb})$ & $10^{-8} \mathrm{M}(3 \mathrm{ppb})$ & $10^{-8} \mathrm{M}(3 \mathrm{ppb})$ \\
\hline Determination limit ${ }^{\mathrm{f}}$ & $2 \times 10^{-8} \mathrm{M}(6 \mathrm{ppb})$ & $2 \times 10^{-8} \mathrm{M}(6 \mathrm{ppb})$ & $2 \times 10^{-8} \mathrm{M}(6 \mathrm{ppb})$ \\
\hline Sampling rate & $30 / \mathrm{h}$ & $30 / \mathrm{h}$ & $20 / \mathrm{h}$ \\
\hline
\end{tabular}

a) 1-methyl-4-(4-diethylaminophenylazo)pyridinium chloride; b) 1-methyl-4-(4-diethylaminophenylazo)pyridinium iodide; c) peak height corresponding to $10^{-7} \mathrm{M}$ lauryl sulfate $\left(\mathrm{LS}^{-}\right)$; d) 10 determinations of $10^{-6}$ $\mathrm{M} \mathrm{LS}^{-}$; e) corresponding to a signal to noise ratio of 3 ; f) lowest determinable concentration

相, 有機相の接触面積が大きく, 抽出速度が大きいため と考えられ，この効果は抽出コイルの短い場合に大きく 寄与することになる.

実用上はベースラインの安定性とピークの再現精度を 考慮して 1 2 m 長の抽出コイルを用いるため, セグメ ンターには特別なものを用いる必要はないと思われる. 洗剤の定量では $2 \mathrm{~m}$ 長のものを用いることにした.

\section{3・4 検量線及び再現性}

Fig. 9 に検量線用フローシグナルの例を示す. MB 法, MEP·Cl 法, MEP·I 法いずれにおいても良好な直 線関係を示している. Table 1 に 3 法の操作条件及び感 度, 再現性などの比較を示す. 感度の点からは MB 法 が優れているが, $3 \times 10^{-8} \mathrm{M}$ 以下の洗剤を含む試料で は負のピークとなり, ピークの判断が困難となるため, 実際の定量下限は MEP·Cl 法と同程度となる．相対標 準偏差（R.S.D.）を比較すると MB 法では吸着性のた めに MEP·Cl 法に比べ若干悪い.

結論としては, 二流路系でも三流路系とほぼ同程度の 感度が得られ, MEP・Cl 法, MB 法いずれも大差な く, 実際分析に用いることができる. バッチ式マニュア ル分析法の JIS 法" ${ }^{1)}$ ではメチレンブルーークロロホルム

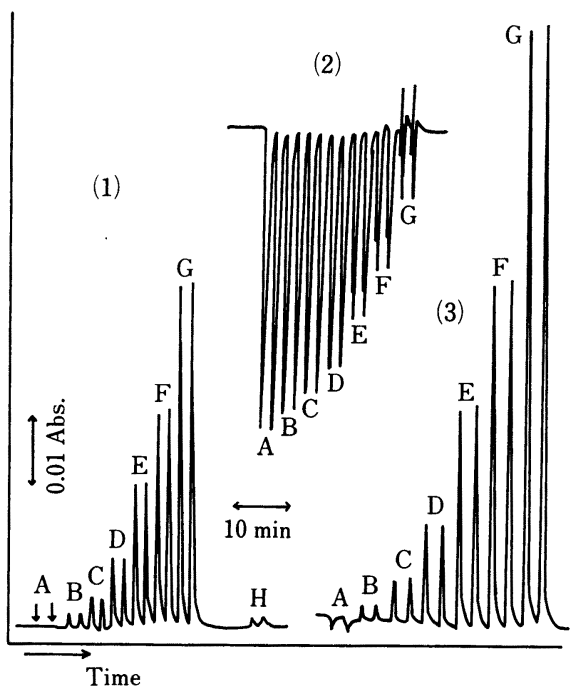

Fig. 9 Flow signals for calibration graphs

(1) MEP.Cl method; (2) MEP.I method; (3) MB method. Conditions: see Table 1. Anionic surfactant (laurylsulfate) $/ 10^{-7} \mathrm{M}:$ (A) 0 ; (B) 0.5 ; (C) $1 ;$ (D) 2 ; (E) $4 ;$ (F) 6 ; (G) $10 ;$ (H) tap water 
抽出法を採用しているが, 本 FIA 装置で 0 -ジクロロベ ンゼンとクロロホルムを比較したところ, クロロホルム 法は 0 -ジクロロベンゼン法に比べ $25 \%$ ピーク高さは小 さかった．プランジャ一型ポンプ使用の場合には低沸点 の溶媒は吸引時に気化し, 送液が一定とならない場合が ある.このような理由からすれば, 沸点の高い 0 -ジク ロロベンゼン（b.p. $181^{\circ} \mathrm{C}$ ) を用いるメチレンブルー法 が最も好ましいであろう。

\section{文献}

1) JIS K 0102, 工場排水試験方法 (1986).

2) "Standard Methods for the Examination of Water and Waste Water," 14th Ed., p. 600 (1975), (American Public Health Association, Washington, DC).

3) S. Motomizu, S. Fujiwara, A. Fujiwara, K. Tôei : Anal. Chem., 54, 392 (1982).

4) 山本幸市, 本水昌二: 分析化学, 36,335 (1897).

5) K. Yamamoto, S. Motomizu : Analyst (London), 112, 1405 (1987).

6) B. Karlberg, S. Thelander : Anal. Chim. Acta, 98, 1 (1978).

7) J. Kawase, A. Nakae, M. Yamanaka : Anal. Chem., 51, 1640 (1979).

8) T. Imasaka, T. Harada, N. Ishibashi : Anal. Chim. Acta, 129, 195 (1981).

9) S. Motomizu, Y. Hazaki, M. Oshima, K. Tôei : Anal. Sci., 3, 265 (1987).

10) S. Motomizu, M. Oshima, T. Kuroda : Analyst (London), 113, 747 (1988).

饮

FIA of anionic surfactants using a double-line solvent extraction system. Shoji Мотомгzu and Katsuhiko Korechika (Department of Chemistry, Faculty of Science, Okayama University, 3-1-1, Tsushimanaka, Okayama-shi
Okayama 700)

FIA of anionic surfactants was examined by using a double-line system in respect to practical application. A reagent solution and an extraction solvent were propelled by a double-plunger pump. Sample solutions were injected into a reagent solution stream, which was marged in a extraction solvent stream. An improved segmentor with an outlet of $0.25-\mathrm{mm}$ bore and $13-\mu$ l space made smaller segments (averaged length, $2 \mathrm{~mm}$ ), which enabled to have higher peaks. The efficiency of the smaller segments on the peak height was higher when the extraction tubing was shorter than $1 \mathrm{~m}$. Three kinds of reagent solutions were examined; one comprised 1methyl-4-(4-diethylaminophenylazo) pyridinium (MEP) chloride (extraction solvent, chloroform ; $\mathrm{MEP} \cdot \mathrm{Cl}$ method), another an iodide of MEP (extraction solvent, chloroform; MEP.I method) and the other methylene blue (extraction solvent, $o$-dichlorobenzene; MB method). By the MEP.I method, negative peaks were obtained in the range below $10^{-6} \mathrm{M}$ of anionic surfactants. The highest peaks were obtained by the MB method. The peak height, the standard deviation and the relative standard deviation obtained by 10 times injection of $10^{-6} \mathrm{M}$ laurylsulfate $\left(\mathrm{LS}^{-}\right)$were $200.6 \mathrm{~mm}$, $0.8 \mathrm{~mm}$ and $0.4 \%$, respectively, by the MB method; $121.1 \mathrm{~mm}, 0.3 \mathrm{~mm}$ and $0.3 \%$, respectively, by the MEP.Cl method. The detection limit corresponding to a signal to noise ratio $(S / N)$ of 3 was about $1 \times 10^{-8} \mathrm{M}$ of $\mathrm{LS}^{-}$by the $\mathrm{MB}$ and MEP. $\mathrm{Cl}$ methods. This method was capable of analyzing 20 30 samples per hour.

(Received May 1, 1989)

\section{Keyword phrases}

solvent extraction/FIA; anionic surfactants determination; methylene blue as an counter ion; 1-methyl-4-(4-diethylaminophenylazo)pyridinium as an counter ion. 